ISSN 2776-1657 (online) 2828-223X (printed)

Volume 1, Number 2, September 2021, Page 98-107

Website: https://journal.walisongo.ac.id/index.php/jieed

\title{
Penerapan Pembelajaran Tematik Berbasis Problem-Based Learning untuk Meningkatkan Hasil Belajar dan Sikap Percaya Diri Siswa
}

\author{
Felakhah Khasanah, ${ }^{1 *}$ Ratnasari Dyah Utami, ${ }^{2}$ Sri Hartati ${ }^{3}$ \\ 1Sekolah Dasar Negeri 1 Kutoharjo, Universitas Terbuka, \\ 2 Universitas Muhammadiyah Surakarta, ${ }^{3}$ Sekolah Dasar Negeri 1 Sobokerto \\ *Penulis korespondensi: khasanahfelakhah@gmail.com
}

DOI : https://doi.org/10.21580/jieed.v1i2.9220

Received: 2021-09-15, Revised: 2021-11-01,

Accepted: 2021-11-02, Published: 2021-11-06

\begin{abstract}
Abstrak
Keterlibatan siswa Sekolah Dasar di dalam proses pembelajaran masih menghadapi berbagai permasalahan. Salah satunya adalah karena guru masih cenderung menjadi pusat atau aktor utama. Penelitian tindakan kelas ini bertujuan untuk meningkatkan hasil belajar dan sikap percarya diri peserta didik pada pembelajaran tematik materi energi melalui penerapan strategi pembelajaran berbasis masalah. Partisipan penelitian ini berjumlah 17 siswa Sekolah Dasar yang terdiri dari 6 lakilaki dan 11 perempuan. Penelitian tindakan kelas ini dilaksanakan dalam dua siklus pembelajaran. Teknik pengumpulan data yang digunakan adalah observasi dan tes, dimana data yang diperoleh dianalisa secara kuantitatif dan kualitatif. Hasil penelitian ini menunjukkan bahwa pembelajaran berbasis masalah dapat meningkatkan hasil belajar siswa pada materi energi, sikap percaya diri dan aktif di dalam proses pembelajaran.
\end{abstract}

Kata Kunci: pembelajaran tematik, pembelajaran berbasis masalah, partisipasi siswa di kelas, pembentukan karakter siswa

\section{Implementation of Problem-Based Thematic Learning to Improve Learning Outcomes and Students' Self-Confidence}

\begin{abstract}
The involvement of elementary school students in the learning process still faces various problems. One of them is because the teacher still tends to be the center or the main actor. This classroom action research aims to improve learning outcomes and students' self-confidence in the thematic learning of energy materials through the application of problem-based learning strategies. The participants of this study were
\end{abstract}


17 elementary school students consisting of 6 boys and 11 girls. This classroom action research was carried out in two learning cycles. The data collection techniques used were observation and tests, where the data obtained were analyzed quantitatively and qualitatively. The results of this study indicate that problem-based learning can improve student learning outcomes in terms of energy, self-confidence and activeness in the learning process.

Keywords: thematic learning, problem-based learning, student participation in class, student character building

\section{PENDAHULUAN}

Pembelajaran tematik terpadu merupakan pendekatan pembelajaran yang direkomendasikan oleh kurikulum 2013 untuk jenjang Sekolah Dasar dan Madrasah Ibtidaiyah. Dalam pembelajaran tematik terpadu, guru mendesain pembelajaran berdasarkan tema yang dikaitkan dan dibahas dengan beberapa mata pelajaran tertentu dengan tujuan memberikan peserta didik pengetahuan dan pengalaman yang bermakna (Firdaus \& Badriyah, 2018; Putri \& Wardani, 2021).

Febriani \& Rahmatina (2020) menyebutkan bahwa salah satu tujuan pembelajaran tematik adalah memfasilitasi peserta didik dengan pemahaman materi yang tidak hanya mendalam, namun juga memberikan kesan dan makna melalui keterkaitan materi dengan pengalaman pribadi peserta didik, terlebih memberikan mereka kesempatan menjadi pelaku utama dari proses pembelajaran. Disinilah proses pembelajaran yang berorientasi pada pembelajaran berpusat pada peserta didik (student-centered learning) akan terjadi.

Salah satu penekanan utama dari pembelajaran tematik adalah perancangan kegiatan pembelajaran yang menyenangkan dan penggunaan media yang beragam untuk mencapai tujuan pembelajaran. Fokus dari pembelajaran tematik terpadu adalah membekali dan membentuk peserta didik agar mampu berpikir kritis, bersikap aktif, kreatif memecahkan masalah yang dihadapi, dan menelaah serta mengolah informasi untuk pemecahan masalah yang diperoleh (Tri, Roemintoyo, \& Yamtinah, 2018). Dari sini, dapat diketahui bagaimana menghadapi masalah dan memecahkan masalah menjadi hal krusial bagi peserta didik dalam pembelajaran tematik terpadu karena kompetensi tersebut menjadi kompetensi yang akan membekali peserta didik dalam menghadapi kehidupan dimasa yang akan datang.

Berdasarkan pengalaman dalam mengajar dan pengamatan yang peneliti pertama lakukan selama ini, kondisi pembelajaran tematik di Sekolah Dasar mengalami beberapa kendala atau permasalahan seperti pembelajaran yang menjadikan guru sebagai pusat atau aktor utama. Pelibatan peserta didik dalam proses pembelajaran masih kurang karena beberapa hal seperti peserta didik yang cenderung malu dan tidak terbiasa mengeluarkan pendapatnya. Akhirnya, guru hanya melakukan ceramah (pembelajaran yang selama ini dianggap konvensional) 
dalam pembelajarannya sehingga peserta didik terlihat dan terkonfirmasi bosan dalam setiap pembelajaran.

Hal ini selaras dengan apa yang telah secara empiris dilaporakan oleh Wulandari, Sudatha, \& Simamora (2020), bahkan dalam beberapa kasus kebosanan tersebut berdampak pada ketidak aktivan peserta didik dalam proses belajar (Arianti, Wiarta, \& Darsana, 2019). Tentunya, kebosanan dan ketidak aktivan tersebut akan mempunyai implikasi pada hasil belajar peserta didik. Ulinnuha, Waluya, \& Rochmad (2021) mengungkap bahwa hasil belajar peserta didik dari suatu proses pembelajaran sangat bergantung pada pada yang didisain dan direncanakan oleh guru.

Dalam konteks penelitian ini, kondisi yang telah diuraikan sebelumnya juga terjadi di tempat yang menjadi penelitian ini. Berdasarkan hasil studi awal peneliti, pembelajaran tema 9 tentang Kayanya Negeriku belum menunjukkan hasil yang menggembirakan. Selain aspek kuantitatif hasil belajar yang belum maksimal, aspek pencaian sikap seperti kritis, aktif, dan kreatif belum muncul dalam diri peserta didik. Ini berarti hakikat dan tujuan dari pembelajaran tematik terpadu belum tercapai.

Selain itu, tema 9 Kayanya Negeriku merupakan salah satu tema yang sangat dekat dengan kehidupan sehari-hari peserta didik sehingga permasalahan yang dimunculkan sangat dengan kehidupan mereka dan harapannya adalah mereka tidak hanya mengkonstruksi pengetahuan mereka tapi juga mampu memecahkan masalah yang mereka hadapi. Keadaan seperti ini menuntut guru yang mengajar untuk mencari solusi dan inovasi agar masalah tersebut dapat diatasi. Salah satu model pembelajaran yang dapat digunakan adalah pembelajaran berbasis masalah (Problem-Based Learning).

Pembelajaran berbasis masalah adalah suatu pembelajaran yang menjadikan peserta didik sebagai pelaku utama sehingga memacu keaktivan dalam memecahkan masalah (Putri \& Wardani, 2021). Mereka menambahkan bahwa penyampaian pembelajaran dilakukan dengan menggunakan beberapa langkah dari menyajikan permasalahan, mengajukan pertanyaan, menyediakan momen penyelidikan, hingga membuka sesi dialog.

Menurut Nuraini (2017) dan Rahyubi (2012), Pembelajaran berbasis masalah mendorong guru untuk mengakomodir keterlibatan peserta didik di dalam memecahkan masalah keseharian mereka (otentik). Oleh karena itu, dalam proses memperoleh informasi dan memahami konsep dari topik yang diajarkan peserta didik harus difasilitasi agar memenuhi beberapa tahapan seperti bagaimana menyusun kerangka permasalahan, mengorganisasi dan menginvestigasi masalah, mengumpulkan dan menganalisa data, menyusun fakta yang diperoleh, mengkonstruksi argumen pemecahan masalah baik secara kelompok maupun secara individu. Dua tujuan utama dari beberapa tahapan tersebut adalah agar 
peserta didik mampu mengkonstruksi pengetahuan mereka dan menyelesaikan masalah dunia nyata yang mereka hadapi.

Hasil penelitian terdahulu telah melaporkan bahwa pembelajaran berbasis masalah mampu meningkatkan hasil belajar peserta didik Sekolah Dasar (Hayati, Firman, \& Desyandri, 2021; Nuraini, 2017; Putri \& Wardani, 2021; Yosepina, 2020). Misalnya, hasil penelitian Hayati, Firman, \& Desyandri (2021) telah menunjukkan bahwa pembelajaran berbasis masalah ini mampu meningkatkan hasil belajar peserta didik pada materi kelas V SD dengan tema ekosistem muatan IPA. Hasil penelitian Nuraini (2017) melaporkan bahwa pembelajaran berbasis masalah tidak hanya meningkatkan hasil belajar peserta didik pada materi IPA, tetapi juga aspek kognitif, afektif, dan psikomotorik meskipun mereka tidak menyebutkan secara detail bagaimana aspek-aspek tersebut mampu difasilitasi oleh pembelajaran yang mereka desain.

Adapun hasil penelitian Yosepina (2020) telah melaporkan bahwa pembalajaran berbasis masalah dapat meningkatkan aktivitas guru dan peserta didik yang berdampak pada peningkatan hasil belajar peserta didik. Sementara itu, Putri \& Wardani (2021) telah menemukan seting berbeda dari Pembelajaran Berbasis Masalah ini, dimana temuan mereka menunjukkan efektivitas model tersebut dalam meningkatkan hasil belajar tematik peserta didik dalam seting pembelajaran dalam jaringan (online).

Dari peneltian terdahulu yang disebutkan tersebut, ada beberapa jurang yang dapat diisi dari penelitian tersebut. Pertama, penelitian tersebut lebih fokus pada peningkatan hasil belajar yang dideskripsikan secara kuantitatif. Kedua, aspek afektif yang menjadi fokus dari pembelajaran tematik dan Pembelajaran Berbasis Masalah kurang dieksplorasi secara tuntas. Ketiga, beragam materi yang diajarkan dalam penelitian tersebut tidak ada yang sama dengan penelitian yang peneliti lakukan ini yaitu materi sumber energi. Sebagian besar penelitian terdahulu lebih berkutat pada aspek pertama sehingga melupakan aspek kedua. Padahal Penelitian Tindakan Kelas yang dilakukan sebenarnya tidak hanya ditujukan untuk meningkatkan hasil belajar saja, namun juga perilaku mengajar guru serta sikap belajar peserta didik agar menjadi lebih baik. Berdasarkan jurang dan kondisi tersebut, Penelitian Tindakan Kelas ini bertujuan untuk mengisi jurang sekaligus berupaya meningkatkan hasil belajar peserta didik materi sumber energi dalam pembelajaran tematik berbasis Probelm-Based Learning di kelas IV Sekolah Dasar.

\section{METODE}

Penelitian merupakan penelitian tindakan kelas dimana peneliti pertama melakukan praktik pembelajaran di kelas yang diajarnya dengan tujuan untuk meningkatkan pembelajaran yang dilakukan di kelas (Mettetal, 2002). Dalam penelitian ini, peneliti pertama sebagai guru kelas bermaksud meningkatkan hasil 
belajar peserta didik melalui perubahan yang dilakukan dalam praktik pembelajarannya.

Penelitian Tindakan Kelas ini dilaksanakan dalam dua siklus pembelajaran dimana setiap siklus dilaksanakan sesuai prinsip perencanaan tindakan, pelaksanaan tindakan, pengamatan, dan refleksi (Hopkins, 1993). Siklus dilaksanakan sampai proses tujuan pembelajaran dicapai. Untuk mencapai perubahan yang diharapkan, siklus juga didesain dalam kerangka mengikuti unsur-unsur yang ingin diselidiki.

Lokus penelitian ini adalah kelas IV B dari SDN 1 Kutoharjo tahun pelajaran 2020/2021, Kecamatan Kaliwungu, Kabupaten Kendal. Partisipan dari penelitian ini sebanyak 17 peserta didik yang terdiri dari 6 laki-laki dan 11 perempuan. Mereka direkrut secara purposif dengan beberapa pertimbangan seperti mempelajari materi sumber energi, akses untuk penelitian, dan kesedian partisipan untuk diteliti yang semuanya dikonfirmasi dengan informed consent atau lembar persetujuan setelah penjelasan.

Teknik pengumpulan data dalam Penelitian Tindakan Kelas ini adalah dengan observasi dan tes. Observasi digunakan untuk mengetahui bagaimana guru melakukan perencanaan hingga tindakan pembelajaran di kelas. Karakteristik observasi yang dilakukan peneliti adalah observasi partisipatif dengan tujuan lebih aktif terlibat dalam kegiatan pembelajaran agar mendapatkan data yang lebih kaya dan mendalam. Data yang diperoleh dari observasi ini akan dianalisa secara kualitatif sehingga aspek afektif dan psikomotorik dapat diketahui. Sementara test yang digunakan terdiri dari pre-test dan post-test untuk mengukur aspek kognitif peserta didik atau hasil belajar peserta didik yang dianalisa secara kuantitatif.

\section{HASIL}

Penelitian tindakan kelas ini dilaksanakan dalam dua siklus. Dalam materi energi tema 9 sub tema 1, ada dua cakupan materi yang menjadi fokus dalam penelitian ini yaitu Ilmu Pengetahuan Alam dan Bahasa Indonesia. Sebelum melakukan proses pembelajaran, peneliti mendesain perangkat pembelajaran yang terdiri dari RPP, materi, media pembelajaran, LKPD, dan evaluasi pembelajaran. Media pembelajaran yang digunakan disini adalah Power Point untuk presentasi dan Video Pembelajaran. Semua tahapan tersebut menganut prinsip yang terdiri dari perencanaan, pelaksanaan dan observasi, dan tahap refleksi.

Dalam Siklus I, tahapan pembelajaran inti terdiri dari mengamati, komunikasi, interaksi dan refleksi. Dalam tahap mengamati ini, peneliti mengajak peserta didik untuk melakukan pengamatan agar mereka mampu menyebutkan pemanfaatan sumber energi air dalam kehidupan sehari-hari. Setelah itu, mereka 
mengkomunikasikan hasil pengamatan mereka dengan rekan sejawat mereka. Apa yang mereka komunikasikan dipandu dengan LKPD yang telah mereka isi dalam tahap sebelumnya. Tahapan komunikasi bersifat dinamis, dimana setelah interaksi atau kolaborasi dengan rekan sejawat atau kelompoknya mereka kembali mengkomunikasikan atau mempresentasikan hasil pekerjaan mereka keseluruh anggota kelas. Pada tahap interaksi, peserta didik melakukan percobaan tentang cara kerja listrik pada alat elektronik dalam kehidupan sehari-hari mereka. Dalam percobaan ini, mereka menganalisis perubahan energi pada peralatan yang menggunakan energi listrik di sekitar mereka lingkungan mereka. Tahap komunikasi dilakukan dengan menyajikan laporan hasil pengamatan dan analisa cara kerja listrik pada alat-alat elektronik di sekitar mereka yang dituangkan dengan cara menuliskan jawaban pada lembar kertas yang telah disediakan oleh guru.

Semua kegiatan yang disebutkan diatas berorientasi pada pembelajaran IPA yang dipadukan dengan pelajaran Bahasa Indonesia yaitu mengamati lingkungan sekitar peserta didik. Dalam materi ini, siswa diajak untuk mengidentifikasi dan belajar kata-kata sulit dari lingkungan di sekitar mereka. Peserta didik juga diminta untuk menyusun pertanyaan yang akan digunakan dalam wawancara terhadap informan di sekitar mereka. Mereka diminta untuk menggali informasi tentang fungsi lingkungan dan menuliskan hasil wawancara tersebut secara naratif sebagai laporan. Dalam penulisan laporan ini, pserta didik harus menggunakan kosakata baku dan kalimat efektif dalam bentuk teks tulis.

Berdasarkan evaluasi pembelajaran, persentase ketuntasan peserta didik dalam materi ini hanya 71,42\%. Tentu saja hasil pembelajaran tematik materi ini belum mendapatkan hasil sesuai dengan yang diharapkan karena capaian yang diharapkan pada tahap ini adalah sebesar 75\%. Setelah itu, peneliti melakukan refleksi terhadap pembelajaran yang dilakukan pada Siklus I. Dari hasil refleksi tersebut, ada beberapa temuan yang peneliti temukan seperti kurang aktifnya peserta didik dalam proses pembelajaran. Selain itu, kepercayaan diri dan keberanian mereka dalam mengutarakan pendapat juga belum nampak sebagaimana yang terlihat dalam sesi tanya jawab dan diskusi. Peneliti menyadari karena mereka sudah lama tidak terlibat dalam pertemuan pembelajaran karena terlalu lama belajar dari rumah. Selain itu, projek yang diberikan juga masih berupa tulisan dan mengisi LKPD sehingga antusiasme mereka kurang terlihat. Permasalahan lainnya adalah karena peserta didik belum terbiasa dengan Pembelajaran Berbasis Masalah, mereka masih kesulitan memahami permasalahan yang disajikan oleh guru. Hasil refleksi inilah yang kemudian akan dijadikan dasar dalam melakukan perbaikan pada siklus berikutnya.

Dalam Siklus II, tahapan pembelajaran yang dilakukan hampir sama dengan Siklus I. Cakupan materi sama yaitu IPA dan Bahasa Indonesia. Tahapan pembelajaran inti juga meliputi mengamati, komunikasi, interaksi, dan refleksi. 
Peserta didik melakukan pengamatan dari permasalahan yang disajikan guru yang diikuti dengan instruksi menyebutkan contoh masing-masing sumber energi dan membedakannya. Setelah itu mereka membuat peta konsep yang berisi tentang manfaat energi matahari bagi kehidupan. Kegiatan yang sama dengan Siklus I adalah wawancara dimana kegiatannya sama dengan sebelumnya diawali dengan merancang daftar pertanyaan kemudian mewawancarai tentang fungsi Sumber Energi dari orang-orang sekitar tempat tinggal. Perbedaannya adalah mereka harus merekam video wawancara yang mereka lakukan.

Dari hasil evaluasi pembelajaran Siklus II, hasil pembelajaran dengan tema 7 sub tema 2 pembelajaran pertama ini adalah sebesar $90,47 \%$ dari seluruh peserta didik yang tuntas dari nilai $\mathrm{KKM} \geq 80$. Artinya, terdapat peningkatan persentase ketuntasan dari Siklus I ke Siklus II. Hasil ini membuktikan bahwa Pembelajaran Berbasis Masalah dalam materi energi ini berhasil. Detail perbandingan hasil belajar Siklus I dan Siklus II tersaji dalam tabel 1 tentang hasil belajar tematik materi energi Siklus I dan Siklus II berikut ini:

Tabel 1

Hasil Belajar Tematik Materi Energi antara Siklus I dan Siklus II

\begin{tabular}{lccc}
\hline Skor & Kriteria & \multicolumn{2}{c}{ Persentase } \\
\hline & & Siklus I & Siklus II \\
$<80$ & Tidak Tuntas & $71,42 \%$ & \\
$\geq 80$ & Tuntas & & $90,47 \%$ \\
\hline
\end{tabular}

Sumber: dokumen pribadi penulis

Sementara itu, hasil refleksi Siklus II ini menyebutkan bahwa keterlibatan siswa mulai mengalami peningkatan dalam menyelesaikan LKPD. Salah satu faktornya adalah peserta didik sudah familiar dengan konsep pembelajaran berbasis masalah. Hal itu menunjukkan bahwa pembiasaan dapat membantu penyelesaian soal yang berbasis masalah baik secara berkelompok maupun individu. Selain itu, pemahaman dasar peserta didik dalam memecahkan masalah yang terdapat dalam soal juga mulai menunjukkan peningkatan. Hal ini ditunjukkan sebagaimana peserta didik mulai aktif terlibat dalam berdiskusi untuk menyelesaikan permasalahan yang disajikan oleh guru.

Perbaikan yang dilakukan oleh guru dalam menanya dan memilih cara untuk menyelesaikan masalah sudah tepat. Dengan pendampingan dan penekanan semua pendapat itu penting membantu peserta didik untuk mulai percaya diri dalam mengkomunikasikan jawaban yang diperoleh dari diskusi. 
Aktivitas peserta didik yang semakin meningkat ini berdampak pula pada hasil pembelajaran yang semakin membaik. Hal itu menunjukkan bahwa siswa sudah mulai terbiasa dengan penyelesaian masalah secara berkelompok sehingga siswa mengalami peningkatan setelah melakukan pembelajaran dengan PBL. Indikator keberhasilan dari rata-rata hasil belajar Siklus I dan Siklus II persentase ketuntasa dari 71, 42\% menjadi 90, 47\%.

\section{PEMBAHASAN}

Hasil temuan penelitian tindakan kelas ini menunjukkan bahwa pembelajaran berbasis masalah secara empiris mampu membantu siswa untuk meningkatkan hasil belajar mereka. Akan tetapi, penggunaan pembelajaran berbasis masalah tidak langsung meningkatkan hasil belajar siswa. Aryulina, \& Riyanto (2016) menjelaskan bahwa pembelajaran berbasis masalah memerlukan pembiasaan dan pengenalan pra kondisi untuk dapat meningkatkan hasil belajar siswa.

Penggunaan pendekatan pembelajaran yang tepat, pengoptimalan pembelajaran berbasis masalah untuk mendorong siswa lebih aktif, kreatif dalam memecahkan masalah yang dihadapinya akan dapat meningkatkan hasil belajar siswa. Temuan ini selaras dengan apa yang telah dilaporkan oleh (Putri \& Wardani, 2021; Winoto \& Prasetyo, 2020).

Disisi lain, pembelajaran berbasis masalah memotivasi siswa untuk lebih berani dan percaya diri sebagaiman terlihat dalam proses tanya jawab dan diskusi yang dilakukan di kelas. Akan tetapi, peneliti tidak serta merta mendapatkan manfaat ini ketika mengajar di kelas. Diperlukan pendekatan khusus yang membuat nyaman peserta didik sehingga mereka berani bertanya tanpa ada kekhawatiran untuk ditertawakan atau diejek rekan sejawat mereka. Bagaimana siswa merasa nyaman tidak adalah dengan memberikan penegasan bahwa setiap ide adalah berharga yang dilakukan secara berulang-ulang. Faktor kenyamanan dan kesenangan telah terbukti menjadi unsur utama dalam keberhasilan pembelajaran berbasis masalah (Tiwari, Lai, So, \& Yuen, 2006).

Selain itu, pembagian peran pada saat kerja kelompok atau diskusi memungkinkan peserta didik untuk memainkan perannya masing-masing sehingga mereka tidak hanya diam melihat teman mereka aktif terlibat dalam pembelajaran. Selanjutnya, panjang durasi waktu yang tersedia juga menjadi hal krusial bagi penerapan pembelajaran berbasis masalah. Penerapan pembelajaran berbasos masalah membutuhkan waktu lebih agar siswa dapat berhasil dalam proses pembelajaran (Ulinnuha et al., 2021).

Jumlah siklus yang dilakukan untuk setiap materi tidak sama karena dipengaruhi oleh faktor tingkat kesulitan materi dan kefamiliaran siswa dengan 
topik bahasan. Pembentukan dan perubahan sikap tertentu yang ingin dicapai dalam pembelajaran juga selalu berbeda dalam tiap prosesnya. Temuan empiris penelitian ini adalah bahwa penerapan pembelajaran tematik dengan model pembelajaran berbasis masalah dapat meningkatkan hasil belajar siswa jika guru memiliki persiapan yang matang sebelum melaksanakan proses pembelajaran.

\section{SIMPULAN}

Penelitian tindakan kelas ini bertujuan untuk meningkatkan hasil belajar siswa pada materi sumber energi melalui penerapan pembelajaran tematik berbasis Probelm-Based Learning di kelas IV Sekolah Dasar. Data penelitian ini menunjukkan bahwa pembelajaran berbasis masalah dapat meningkatkan hasil belajar siswa pada materi energi. Selain itu, penelitian ini juga mengungkap bahwa pembelajaran tematik berbasis masalah dapat membentuk sikap percaya diri dan aktif di dalam proses pembelajaran. Meski demikian, sebelum menggunakan model pembelajaran ini, guru harus mempertimbangkan durasi waktu yang dibutuhkan, faktor kenyamanan lingkungan belajar siswa, dan bahan-bahan yang diperlukan saat menjelaskan materi pelajaran.

\section{UCAPAN TERIMA KASIH}

Penulis mengucapkan terima kasih kepada seluruh partisiapan atas kesediaan mereka berpartisipasi dalam riset ini serta pihak SDN 1 Kutoharjo yang telah memberikan akses dan ijin untuk penelitian ini.

\section{DAFTAR PUSTAKA}

Arianti, N. M., Wiarta, I. W., \& Darsana, I. W. (2019). Pengaruh Model Pembelajaran Problem Posing Berbantuan Media Semi Konkret terhadap Kompetensi Pengetahuan Matematika. Jurnal Ilmiah Sekolah Dasar, 3(4), 385-393.

Aryulina, D., Aryulina, D., \& Riyanto, R. (2016). A Problem-Based Learning Model in Biology Education Courses to Develop Inquiry Teaching Competency of Preservice Teachers. Jurnal Cakrawala Pendidikan, 35(1).

Febriani, D., \& Rahmatina, R. (2020). Peningkatan Proses Pembelajaran Tematik Terpadu Dengan Menggunakan Model Problem Based Learning di Kelas V Sekolah Dasar. Jurnal Pendidikan Tambusai, 4(3), 2354-2359.

Firdaus, F. M., \& Badriyah, N. (2018). Penerapan Pembelajaran Tematik Berbasis Budaya Betawi untuk Meningkatkan Visual-Spatial Intelligence Siswa SD Islam Tam Quraniyah. Pedagogik (Jurnal Pendidikan Sekolah Dasar), 6(2), 100-108. 
Hayati, F., Firman, F., \& Desyandri, D. (2021). Analisis hasil belajar tematik siswa dengan strategi pembelajaran berbasis masalah di sekolah dasar. JRTI (Jurnal Riset Tindakan Indonesia), 6(1), 46-50.

Hopkins, D. (1993). A Teacher's Guide to Classroom Research. Philadelphia: Open University Press.

Mettetal, G. (2002). The What, Why and How of Classroom Action Research. Journal of the Scholarship of Teaching and Learning, 6-13.

Nuraini, F. (2017). Penggunaan Model Problem Based Learning (PBL) untuk Meningkatkan Hasil Belajar IPA Siswa Kelas 5 SD. E-Jurnal Mitra Pendidikan, 1(4), 369-379.

Putri, R. H., \& Wardani, N. S. (2021). Peningkatan Hasil Belajar Tematik Melalui Problem Based Learning dalam Pembelajaran Daring Siswa Kelas IV SD. Mimbar Ilmu, 26(1), 138-148.

Rahyubi, H. (2012). Teori-Teori Belajar dan Aplikasi Pembelajaran Motorik. Majalengka: Nusa Media.

Tiwari, A., Lai, P., So, M., \& Yuen, K. (2006). A comparison of the effects of problembased learning and lecturing on the development of students' critical thinking. Medical Education, 40(6), 547-554.

Tri, M., Roemintoyo, R., \& Yamtinah, S. (2018). Textbooks Thematic Based Character Education on Thematic Learning Primary School: An Influence. International Journal of Educational Methodology, 4(2), 75-81.

Ulinnuha, R., Waluya, S. B., \& Rochmad, R. (2021). Creative Thinking Ability With Open-Ended Problems Based on Self-Efficacy in Gnomio Blended Learning. Unnes Journal of Mathematics Education Research, 10(A), 20-25.

Winoto, Y. C., \& Prasetyo, T. (2020). Efektivitas Model Problem Based Learning Dan Discovery Learning Terhadap Kemampuan Berpikir Kritis Siswa Sekolah Dasar. Jurnal Basicedu, 4(2), 228-238.

Wulandari, I. G. A. A. M., Sudatha, I. G. W., \& Simamora, A. H. (2020). Pengembangan Pembelajaran Blended Pada Mata Kuliah Ahara Yoga Semester II di IHDN Denpasar. Jurnal Edutech Undiksha, 8(1), 1-15.

Yosepina. (2020). Peningkatan Hasil Belajar Siswa Pada Pembelajaran Tematik dengan Problem Based Learning di Kelas V SD Negeri 46 Pare PAre. $A L$ ATHFAL : Jurnal Pembelajaran Dan Pendidikan Anak Usia Dini, 2(2). 